\title{
The effect of career information service on improving students' career understanding
}

\author{
Tampasera Datar \\ Guidance and Counseling, SMK Negeri 6 Takalar, Indonesia \\ Email: tampasera16@gmail.com \\ Ahmad \\ Psychology, Universitas Negeri Makassar, Indonesia \\ Email: Ahmadrazak71@gmail.com
}

(Received: 28-October-2018; Reviewed: 12-July-2019; Accepted: 20-December-2019; published: 26-December-2019)

\begin{abstract}
The study aims at discovering description to career understanding of before and after treatment and at discovering career information service has an influence on the career understanding of students. This type of research is a quantitative of research type with an experimental research design of true experimental type. The sampling technique uses random sampling technique with the lottery method. Data collection techniques used two tools, namely the scale of social empathy and observation. Data analysis techniques used descriptive data analysis and inferential data analysis. The results showed that: (1) The level of career understanding of students at before being treated in this case career information services were in the low category, but after being treated the level of career understanding of students had increased or were in the very high category. (2) Career information services have an influence in improving student's career understanding. This means that if the career information service is implemented it will help improve student's career understanding.
\end{abstract}

Keywords: Services; Information; Understanding; Career.

\begin{abstract}
Abstrak: Tujuan Penelitian ini untuk mengetahui gambaran pemahaman karir siswa sebelum dan setelah perlakuan dan untuk mengetahui apakah layanan informasi karir memiliki pengaruh terhadap pemahaman karir siswa. Jenis penelitian ini adalah jenis penelitian kuantitatif dengan desain penelitian eksperimen tipe true eksperimen. Teknik pengambilan sampel menggunakan teknik random sampling dengan metode undian. Teknik pengumpulan data menggunakan dua alat yaitu skala empati sosial dan observasi. Teknik analisis data menggunakan analisis data deskriptif dan analisis data inferensial. Hasil penelitian menunjukkan bahwa: (1) Tingkat pemahaman karir siswa sebelum diberi perlakuan dalam hal ini layanan informasi karir berada pada kategori rendah, akan tetapi setelah diberi perlakuan tingkat pemahaman karir siswa mengalami peningkatan atau berada pada kategori sangat tinggi. (2) Layanan informasi karir memiliki pengaruh dalam meningkatkan pemahaman karir siswa. Artinya apabila layanan informasi karir ini diterapkan akan membantu meningkatkan pemahaman karir siswa.
\end{abstract}

Kata Kunci: Layanan; Informasi; Pemahaman; Karir. 


\section{8 | Jurnal Psikologi Pendidikan \& Konseling Vol. 5 No. 2 Desember 2019}

\section{INTRODUCTION}

Greenbank \& Hepworth (2008) stated that the number of unemployment in a country is an indicator of how poor the high school and university graduates career planning and understanding are. A good career planning is highly related to the students' understanding on the career itself (Srivastava, 2019; Han, 2019; Prescod et al., 2019). A success in achieving career is influenced by the ability to plan and decide it well. Students who have a good planning will be able to understand themselves. Thus, those students will be able to decide what the best thing that suit them is (Zhang et al., 2019; Nulhakim et al., 2019; Carrico et al., 2019).

In a counseling process, there are four aspects that can be discussed, namely personal, study, social, and career matters. The aim of career discussion and help service is to allow students to a themselves and understand the world of work so that they can choose and plan their future career well (Rahma, 2010). Thus, it can be said that career guidance is a process of assistance through various ways and forms of service so that students are able to plan their careers according to their talents, interests, abilities, knowledge, and personality.

A career information service is a means of delivering information that helps students determining the type of work and meeting the criteria so that the selected job is aligned with their potentials (Pustika, 2019). The role of counseling teacher in helping students to plan their careers according to their abilities, talents and interests is very important because entering a work world, some students might not have not been able to understand the workfield's development, and based on this information, someone might be able to test their compatibility with their individual concepts (Wijaya et al., 2019)

This is similar to the opinion by Hidayati (2015) that providing a career information service requires the teacher's creativity to help the students overcoming their problems. The results of research conducted by Dahlan (2015) which revealed that using pictorial media in career information services was effective, as proven by comparing the students' understanding of advanced study before and after being given the services

Next, a research conducted by Hartinah, Wibowo, \& Tadjri (2015) argued that a life skill-based career information service can effectively improve students' understanding of career planning. Another study conducted by Adiputra (2015) showed that modeling techniques can improve career planning, where $86 \%$ of the students who followed counseling with modeling approaches could make career planning optimally as marked by their speed in filling career planning worksheets. Another research by Sitompul (2018) shows the percentage result of students' understanding of career planning which reaches $86 \%$ in the category of very good.

Other related researches conducted by Lestari \& Supriyo (2016); Andriani (2019); Fitri et al. (2016); Zakaria (2018); Muttaqin, Wagimin, \& Tadjri (2017) concluded that there is an influence of career information services, one of which is to improve students' career understanding. Based on the preliminary information gained through observation, interviews, and documents collection, it seems that students' career understanding is still low. One of the indicators that reassures the researchers is the students inability to distinguish between career and work, and students tend to say that they choose a particular major because they follow their neighbors. The provision of career information services along with parental support is very important for the students to decide future career direction. This is supported by Rahman \& Khoirunnisa (2019) who said that parental support also influences student career decision, especially when they have not found their choices. Students tend to decide based on the advice from their parents.

\section{METHOD}

This research is a quantitative study that uses an experimental approach with trueexperimental design in the form of PretestPosttest Control Group Design. The population in this study is all 112 students of class 10 . The sampling uses simple random sampling with purposive technique. The sample of this study is 40 students, which are divided into two groups: 20 students for the experimental group and 20 students for the control group. The data were collected through scale, observation, and descriptive and inferential data analysis.

\section{RESULTS AND DISCUSSION}

The description of students' career understanding levels in the experimental group 
before and after treatment. The results of descriptive analysis conducted using SPSS 22 for Windows show the difference of students' career understanding before and after given the career information service. The recapitulation results of descriptive analysis can be seen in the following

table:

Table 1. Level of Students' Career Understanding Before (Pretest) and After (Posttest) Given Career Information Service

\begin{tabular}{cccccc}
\hline \multirow{2}{*}{ Interval } & \multirow{2}{*}{ Category } & \multicolumn{2}{c}{ Pretest } & \multicolumn{2}{c}{ Posttest } \\
\cline { 3 - 6 } & Frequency & Percentage & Frequency & Percentage \\
\hline $126-150$ & Very High & 0 & 0 & 2 & $10 \%$ \\
$102-125$ & High & 1 & $5 \%$ & 14 & $70 \%$ \\
$78-101$ & Medium & 8 & $40 \%$ & 4 & $20 \%$ \\
$54-77$ & Low & 8 & $40 \%$ & 0 & 0 \\
$30-53$ & Very Low & 3 & $15 \%$ & 0 & 0 \\
\hline & & 20 & 100,00 & 20 & 100,00 \\
\hline
\end{tabular}

Table 1 shows that before given the career information service, the students' career understanding is very low, which means that they have not understood and known their physical and psychological potential, as well as their ability to make career choices that suit their talents and interests easily. Medium and low level of understanding means that only a few of them understand and know their potentials, both physical and psychological potential, as well as their ability to make career choices that suit their talents and interests easily. Meanwhile, high category means that many students do not understand their potentials, both physical and psychological potential, as well as their ability to make career choices that suit their talents and interests easily. There are no respondents in the very high category. Next, based on the average score obtained, the level of understanding students' career understanding is low.

After given career information for four sessions, the level of students' understanding is increasing. This can be seen from the level of understanding that reach very high and high categories, which means that many students have understood and known their physical and psychological potential, as well as are able to choose career that suit their talents and interests easily. Medium understanding level means that there are still some students who have and have not understood and known their their physical and psychological potential, as well as are able to choose career that suit their talents and interests easily.

There are no respondents in the low and very low categories. Next, based on the average score obtained, the student's career understanding level is in the high category. This is in accordance with researches by Wardani \& Trisnani (2019); Mallinson \& Burns (2019); Sari \& Istiqoma (2019) which found out that the research subjects' understanding improved after given career information. This means that the information services could improve students' career understanding.

Table 2. Percentage Data Results of Observation on Career Information Service

\begin{tabular}{rlcccccc}
\hline \multirow{2}{*}{ Percentage } & \multicolumn{1}{c}{ Criteria } & I & II & III & IV & V & VI \\
\cline { 2 - 7 } & Very High & 0 & 0 & 0 & 1 & 6 & 13 \\
\hline $80 \%-100 \%$ & High & 0 & 1 & 8 & 9 & 12 & 7 \\
$60 \%-80 \%$ & Medium & 0 & 6 & 9 & 8 & 2 & 0 \\
$40 \%-59 \%$ & Low & 6 & 13 & 3 & 2 & 0 & 0 \\
$20 \%-39 \%$ & Very Low & 14 & 0 & 0 & 0 & 0 & 0 \\
$0 \%-19 \%$ & Total & 20 & 20 & 20 & 20 & 20 & 20 \\
\hline
\end{tabular}

Table 2 shows the observation results from first meeting to the sixth meeting as a supporting material for career information service activities to improve students' career understanding. The results show that there is an increase in undersatnding, meaning that in the first meeting, many students did not know about 
career information, career understanding, and types of job. Then in the next meeting until the last one, gradually, the number of students who gained career knowledge is increasing. It can be concluded that the more often career information services are provided to students, the higher their level of career understanding will be.
Table 2 shows the results of observation on the control group's career understanding before and after given the treatment. The descriptive analysis conducted using SPSS 22 program for Windows demonstrates the control group's career understanding before and after given career information. The recapitulation result is presented in the following table;

Table 3. The Level of Control Group's Career Understanding Before (Pretest) and After (Posttest) Given Career Information Service

\begin{tabular}{|c|c|c|c|c|c|}
\hline \multirow[t]{2}{*}{ Interval } & \multirow[t]{2}{*}{ Categories } & \multicolumn{2}{|c|}{ Pretest } & \multicolumn{2}{|c|}{ Posttest } \\
\hline & & Frequency & Percentage & Frequency & Percentage \\
\hline $126-150$ & Very High & 0 & 0 & 0 & 0 \\
\hline $102-125$ & High & 1 & $5 \%$ & 5 & $25 \%$ \\
\hline $78-101$ & Medium & 8 & $40 \%$ & 14 & $70 \%$ \\
\hline $54-77$ & Low & 10 & $50 \%$ & 1 & $5 \%$ \\
\hline $30-53$ & Very Low & 1 & $5 \%$ & 0 & 0 \\
\hline \multicolumn{2}{|c|}{ Total } & 20 & 100,00 & 20 & 100,00 \\
\hline
\end{tabular}

Table 3 shows that at the time of the pretest, the level of students' career understanding was very low, meaning that most students have not understood and known their physical and psychological potential, as well as their ability to choose career that suit their talents and interests easily. The result of the post-test indicates that no student is in the very low category. Low category means that some students have not understood and known their physical and psychological potential, as well as their ability to choose career that suit their talents and interests easily during the pretest. After the posttest, students begin to understand and know their physical and psychological potential, as well as are able to choose career that suit their talents and interests easily. The medium category means that some students who have received career information services have not understood and known their physical and psychological potential, as well as are able to choose career that suit their talents and interests easily. After the posttest, most students have understood and potential, as well as are able to choose career that suit their talents and interests easily.

Meanwhile, the high category during the pretest means that there are still many students who do not understand and know their physical and psychological potential, as well as their ability to choose career that suit their talents and interests easily. The high category in the posttest means that there is an increase in the number of students who understand and know their physical and psychological potentials, as well as their ability to choose career that suit their talents and interests easily. There were no respondents in the very high category at the time of the pretest or posttest.

This result indicates that the students' career understanding at the time of the pretest is still low, thus an information service to improve students' career understanding is needed. The posttest on the control group shows that students' understaing is improved. It means that their level of understanding is in the medium category.

Table 4. Percentage Data Results of Observation on Career Information Service

\begin{tabular}{rlcccccc}
\hline \multirow{2}{*}{ Percentage } & \multicolumn{1}{c}{ Criteria } & I & II & III & IV & V & VI \\
\cline { 3 - 7 } & Very high & 0 & 0 & 0 & 0 & 0 & 1 \\
\hline $80 \%-100 \%$ & High & 0 & 0 & 2 & 8 & 10 & 12 \\
$60 \%-80 \%$ & Medium & 0 & 5 & 10 & 12 & 10 & 7 \\
$40 \%-59 \%$ & Low & 6 & 9 & 8 & 0 & 0 & 0 \\
$20 \%-39 \%$ & 14 & 6 & 0 & 0 & 0 & 0 \\
$0 \%-19 \%$ & Very Low & 20 & 20 & 20 & 20 & 20 & 20 \\
\hline
\end{tabular}


Table 4 shows the observation results from the first meeting to the sixth meeting as a supporting material for career information service activities to improve students' career understanding. The results show that there is an increase in understanding, meaning that in the early meeting, many students still did not know about career information, career understanding, and types of job. Then in the next meeting until the last one, gradually, the number of students who gained career knowledge is increasing. It can be concluded that the more often career information services are provided to students, the higher their level of career understanding will be.

The hypothesis of this study is "There is an influence of career information services on improving career understanding". To test this hypothesis, normality test and hongenity test were first perform. These tests were carried out because the inferential test that would be used was the t-test which is part of non parametric test.

T-test can be done because the data have fulfilled the requirements that they must have normal distribution and homogeneous variance. Based on the calculations results using SPSS 22 for Windows, the data show that there is a difference in career understanding before and after career information services are provided. Thus, so the work hypothesis $\left(\mathrm{H}_{1}\right)$ There is an influence of career information services on improving career understanding" is accepted. From the previous statement, it is concluded that the implementation of career information services has a positive influence on improving student career understanding.

The results of the pre-test analysis on 40 subjects in both the experimental and control groups show that the level of students' career understanding before being given career information services was in the low category. A good career understanding can be achieved when the students have the knowledge to look for career information from various sources. To allow students gettig career information, the service was then created.

This service aims to make students understand themselves, know various alternatives and conditions of higher education, know the aspects that need to be considered for entering college, strengthen their decisions, adapt their knowledge, modify unrealistic desires to the world of education, and to adjust the personal conditions with the selected further education so that they get a picture and understanding of the ins and outs of higher education after vocational high school. This relates to the opinion Risqiyain \& Purwanta (2019) whose research states that career information services provide information to students to choose according to their wishes in education and employment so that they are able to choose clearly to achieve their goals

In this study, the competence and skills given to students were packed in 4 meetings. The first meeting was related to selfunderstanding, the second meeting was about introduction of personal skills, the third meeting was on the disclosure of academic potentials, the fourth meeting was about providing information on various professions and positions in the world of work, the fifth meeting was about formal and non-formal education information, and the last meeting focuses on discussion on the career choice that suit the students' talent and interest.

After an intervention in the form of providing career information services, students' career understanding is improved, especially the experimental group. The changes that can be seen is the increase of student participation in the activities from low category to high category. This can occur because students experienced a variety of changes in themselves during the program. The change referred to is their ability to understand and know their physical and psychological potentials, as well their ability to choose career that suit their talents and interests easily.

Observations were not only conducted in the class but also outside. Observations outside the classroom was done by giving assignments to the students to interview various professions at school, and the level of student participation in this activity was very high. This type of assignment shows students an example of how to search for information about careers of their interest. After getting the information, the students who had high enthusiasm wanted to present their interview results. This assignment let the students understand better about the various advantages, disadvantages, and opportunities in choosing a career later.

Based on the above observations, it seems that the changes experienced by the students are caused by the innovative career information services. These changes can be seen immediately during the subjects that suit their 
interests, talents, and direction of career goals by always coming on time, following the lesson well and calmly, and doing the tasks given by the teacher. However, the drawback is that students who already have good career understanding will pay less attention to the subjects that do not suit their career goals.

\section{CONCLUSION AND SUGGESTIONS}

Based on the results and discussion of this study, it can be concluded that: (1) Before being given career information service, the level of career understanding of the experimental group and the control group was low. (2) After given career information, the level of understanding in one group was high, while that in the control group was in the medium category. And (3) the results indicate that career information service is proven to improve students' career understanding.

Based on the above conclusions, the following suggestions are proposed: (1) Counseling teacher should implement a variety of guidance programs, especially career guidance, because each student will face a variety of career choices in the future. Thus, counseling teachers should take part by making an innovative career information programs. (2) Students should interact more with counseling teachers so that they can choose careers that suit their interests and talents. (3) The next researchers, especially those in counseling education, need to develop a friendlier career guidance service so that during the discussion, the students do not feel like they are under a guidance.

\section{REFERENCES}

Adiputra, S. (2015). Prnggunaan Teknik Modeling Terhadap Perencanaan Karir siswa. Jurnal Fokus Konseling, 1(1).

Andriani, M. W. (2019). Pengaruh Layanan Informasi Menggunakan Papan Bimbingan Terhadap Pemahaman Karir Siswa Sekolah Dasar. Nusantara of Research, 6(2), 68-77.

Carrico, C., Matusovich, H. M., \& Paretti, M. C. (2019). A qualitative analysis of career choice pathways of college-oriented rural central Appalachian high school students. Journal of Career Development, 46(2), 94-111.
Dahlan, N. (2015). Efektifitas Informasi Karir dengan Medi Buku Bergambar untuk Meningkatkan Pemahaman Studi Lanjutan Siswa. Jurnal Psikologi Pendidikan dan Bimbingan, 1(1).

Fitri, Fitri , E., Ifdil, I., \& Neviyarni, S. (2016). Efektivitas Layanan Informasi dengan menggunakan metode blended learning untuk meningkatkan motivasi belajar. Jurnal Psikologi Pendidikan dan Konseling; Jurnal Kajian Psikologi Pendidikan dan Bimbingan Konseling, 2(2), 84-92.

Greenbank, P., \& Hepworth, S. (2008). Working Class Students and The Carrier Decision Making Process: a qualitative study. Higher Education Carriers Service Unit (HECSU), Manchester website: http://www.hecsu.ac.uk/working_class_ students_and_the_career_decision_maki ng_process.ht.

Han, Y. (2019, April). Research on College Students' Entrepreneurship Education from the Perspective of Career Planning. In 1st International Symposium on Education, Culture and Social Sciences (ECSS 2019). Atlantis Press.

Hartinah, G., Wibowo, M. E., \& Tadjri, I. (2015). Pengembangan Model Layanan Informasi Karir Berbasis Life Skills untuk Meningkatkan Pemahaman dalam Perencanaan Karir Siswa SMA. Journal Bimbingan dan Konseling, 4(1), 43-48.

Hidayati, R. (2015). Layanan Informasi Karir Membantu Peserta Didik dalam Meningkatkan Pemahaman Karir. Jurnal Konseling GUSJIGANG, 1(1).

Lestari, D., \& Supriyo, S. (2016). Kontribusi Minat Jurusan, Kualitas Layanan Informasi Karir, dan Pemahaman Karir terhadap Kemampuan Mengambil Keputusan Karir. Jurnal Bimbingan Konseling, 5(1), 47-54.

Mallinson, D. J., \& Burns, P. (2019). Increasing Career Confidence through a Course in Public Service Careers. Journal of Political Science Eduvation, 15(2), 161178.

Muttaqin, R., Wagimin, W., \& Tadjri, I. (2017). Keefektifan Layanan Informasi Karier Berbantuan Video Interaktif dan Live Modeling untuk Meningkatkan Pemahaman Karier Siswa SMP. Jurnal Bimbingan Konseling, 6(2), 174-179. 
Nulhakim, L., Wibawa, B., \& Erwin, T. N. (2019, March). Relationship between students' multiple intelligence-based instructional areas and assessment on academic achievements. In Journal of Physics: Conference Series (Vol. 1188, No. 1, p. 012086). IOP Publishing.

Prescod, D., Gilfillan, B., Belser, C., Orndorff, R., \& Ishler, M. (2019). Career Decision-Making for Undergraduates Enrolled in Career Planning Courses. College Quarterly, 22(2), n2.

Pustika, D. (2019). Pengembangan Media Layanan Informasi Karir Berbasis Google Classroom di Sekolah Menengah kejuruan. Jurnal Pendidikan dan Pembelajaran Khatulistiwa, 8(12), $1-9$.

Rahma, U. (2010). Bimbingan Karir Siswa. Malang: UIN Maliki Press.

Rahman, A., \& Khoirunnisa, R. N. (2019). Hubungan Antara Regulasi Emosi dengan Pengambilan Keputusan Karir Pada Siswa Kelas XI SMA Negeri 22 Surabya. Jurnal Penelitian Psikologi, 6(1), 1-6.

Risqiyain, L. H., \& Purwanta, E. (2019). Pengembangan Multimedia Interaktif Informasi karier untuk Meningkatkan Kematangan Kakrir Siswa Sekolah Menengah Kejuruan. Jurnal Kajian Bimbingan dan Konseling, 4(3), 88-93.

Sari, K., \& Istiqoma, V. A. (2019). Upaya Meningkatkan Kemampuan Perencanaan Karier Melalui Bimbingan Karir Media Mind Mapping. Jurnal Wahana Konseling, 2(1), 20-29.

Sitompul, L. (2018). Meningkatkan Pemahaman Perencanaan Karir Melalui Layanan Bimbingan Karir di Sekolah dengan Menggunakan Media Gambar Pada Siswa Kelas IX-1 SMP Negeri 1 Gebang Tahun 2017-2018. Jurnal Tabularasa PPs UNIMED, 15(3), 316327.
Srivastava, S. (2019). Modern Trends In Career Planning With Refernce To Today's Vuca World. Advance and Innovative Research, 178.

Supriyanto, A., Hartini, S., Syamsudin, S., \& Sutoyo, A. (2019). Indicators of professional competencies in research of Guidance and Counseling Teachers. Counsellia: Jurnal Bimbingan dan Konseling, 9(1), 53-64.

Wardani, S. Y., \& Trisnani, R. P. (2019). Efektifitas Modul Informasi Karier dalam Meningkatkan Pemahaman Karir Siswa. Prosiding Seminar nasional Hasil Penelitian LPPM Universitas PGRI Madiun (pp. 37-42). Madiun: LPPM Universitas PGRI Madiun.

Wijaya, R. S., Husniah, W. D., Taherong, R., Nuryadin, C., Hanifa, L., \& Ichsani, N. (2019, February). Professional competency levels teacher guidance and counseling/counselor school. In IOP Conference Series: Earth and Environmental Science (Vol. 235, No. 1, p. 012105). IOP Publishing.

Wong, L. P., \& Yuen, M. (2019). Career Guidance and Counseling in Secondary Schools in Hong Kong: A Historical Overview. Journal of Asia Pacific counseling, 9(1), 1-19.

Zakaria, A. F. (2018). Media Layanan Informasi Karir Sekolah Lanjutan Bagi Siswa (Melankolis) untuk Meningkatkan Pemahaman Siswa dalam Memilih Studi Lanjut Setelah SMP. Journal of Innovative Counseling: Theory, Practice, and Research, 2(02), 32-43.

Zhang, X., Gossett, C., Simpson, J., \& Davis, R. (2019). Advising students for success in higher education: An all-out effort. Journal of College Student Retention: Research, Theory \& Practice, 21(1), 5377. 